\title{
NOTES AND NEWS
}

\author{
NEWSLETTERS
}

The Nilo-Saharan Newsletter has been resurrected and will appear once a year. Its aims are to disseminate information on who is doing what and where within NiloSaharan studies, new publications, conferences and meetings where papers on Nilo-Saharan languages have been or will be given.

The first of the new issues appeared at the end of 1986. Any correspondence should be directed to:

Angela von Funck

Afrikanistik II

University of Bayreuth

Postfach 101251

8580 Bayreuth

Federal Republic of Germany.

Newsletter 11 has been received from the Southern African Research Program at Yale and Wesleyan Universities. It contains details of research, visiting fellows, former visiting fellows, workshops and library acquisitions. For further information, contact Pamela Baldwin, Administrative Assistant to the Program.

Newsletter on African Studies in the Netherlands, No. 6, has appeared, containing a comprehensive listing of recent doctoral dissertations, research projects and valuable indexes of researchers, institutions and areas of study. To obtain copies of this and earlier issues, write to:

Editor Newsletter

African Studies Centre

Stationsplein 12

2312 AK Leiden

The Netherlands.

\section{Network of Scientific Development Research Institutions in Developing Countries}

This was initiated in 1983 and member institutions are engaged in the study of socio-economic development at national and international levels. The main source of information about the developments within the network is the Communication Newsletter which is distributed regularly to all member institutions and prospective members. Institutes and institutions wishing to join the network should complete the 'Network Questionnaire', obtainable from:

Network of Scientific Development Research Institutions in Developing Countries

Institute for Developing Countries

41000 Zagreb, 8.maja 82

Yugoslavia.

\section{AFRICAN BOOKS COLLECTIVE}

Hans Zell announces the formation of African Books Collective, a major new initiative to promote African books in Europe and North America. It has its roots in a meeting held in London in October 1985, jointly convened by the Africa Centre and The African Book Publishing Record, with financial support from a 
number of donor organisations. The meeting brought together a representative group of eleven African publishers. Its purpose was to explore and make firm proposals as to how a consortium of African publishers might collectively market their books in Europe and North America by pooling their resources and knowhow, by producing joint lists and catalogues, and by establishing a small permanent office in the UK to provide centralised order fulfilment, billing and shipping for several publishers. Anyone wishing further information on African publishers involved, range of titles to be stocked, catalogues and promotional material, etc. should address their inquiries to:

Hans Zell

PO Box 56

Oxford

OX1 3EL

Tel. 0865512934.

\section{FORTHCOMING CONFERENCE}

The Centro de Estudos de Historia e Cartografia Antiga in Lisbon is organising an international conference for October 1988, entitled 'Euro-African Relations in the Third Quarter of the Nineteenth Century' and limited to sub-Saharan Africa. The period extends from the withering away of the Atlantic slave trade in the 1850 s to the Brussels Conference of 1876, a time during which most Africans still retained political control over their destinies. The focus of the conference is to be on how Africans used this autonomy in their reaction to the new ideas and forms of organisation proposed by Europeans. For more information, write to:

Comissao Organizadora da Reuniao Internacional de Historia de Africa CEHCA

Rua Jau 54

1300 Lisbon.

\section{NEW IBADAN JOURNAL}

Rural Life: a journal of rural development has been launched at the University of Ibadan. Its editors are S. G. Nwoko (Editor-in-Chief), Department of Agriculture Economics, and T. O. Ogunfiditimi, Agriculture Extension Department. It aims to offer 'opportunities to scholars, developers, financiers, investors, entrepreneurs, planners, organisations and policy-makers to share ideas and experience on the economic changes which are taking place in rural areas'. The journal will appear three times a year, beginning in January 1987. For further details write to Dr S. G. Nwoko at the University of Ibadan, Nigeria.

\section{AFRICAN STUDIES INFORMATION RESOURCES DIRECTORY}

African Studies Information Resources Directory, compiled and edited by Jean E. Meeh Gosebrink, has been published by Hans Zell/Saur. It provides a comprehensive reference and research tool for identifying sources of information and documentation on sub-Saharan Africa located in the United States. 